\title{
Geastrum nanum found in Finland
}

\author{
CARL-ADAM HÆGGSTRÖM
}

\begin{abstract}
HÆGGSTRÖM, C.-A. 1979: Geastrum nanum found in Finland. - Karstenia 19: 19-21.

Geastrum nanum Pers, was found in 1972 in Björkör Nature Reserve in Åland, SW Finland. This is the first find of $G$. nanum from Finland, since an earlier record of the species was based on a misidentification. A description is given of the four gastrocarps from Björkör. The locality, a dry, stony meadow grazed by sheep, has a rather poor and common vascular plant flora. The total distribution of $G$. nanum is described.
\end{abstract}

Carl-Adam Hoeggström, Department of Botany, University of Helsingfors, Unionsgatan 44, SF-00170 Helsingfors 17, Finland

\section{Introduction}

On August 26, 1972, during studies of the vascular plant flora and vegetation of Björkör Nature Reserve in Åland, SW Finland, I found Geastrum nanum Pers. on Björkör Island (Grid $27^{\circ} \mathrm{E} 6667: 121$ ). The determination of the species has been confirmed by Mr. Stellan Sunhede, Göteborg, Sweden. This is the first record of $G$. nanum in Finland. The species has been reported once before, from Sammatti in the province of Ab, SW Finland (Roivainen 1960), but the voucher specimen in $\mathrm{H}$ represents in my opinion G. quadrifidum Pers.

\section{Description of the Finnish material}

The material from Björkör consists of four gastrocarps, three fresh and one weathered.

Exoperidium not hygroscopic, $3.0-4.5 \mathrm{~cm}$ wide (when dry), split to about the middle into 6-9 acute, recurved lobes (rays). Mycelial layer persistent with soil particles adhering to it. Fibrous layer thin, pale brown (whitish gray in the weathered gastrocarp). Pseudoparenchymatous layer dark brown (when dry), sometimes cracked.

Endoperidium dark brown with a whitish farinose surface, subglobose to slightly oval, $0.8-1.3 \mathrm{~cm}$ broad and $0.6-1.1 \mathrm{~cm}$ high, with a short (about 0.5 $\mathrm{mm}$ ) pale brown pedicel. Apophysis pronounced, paler than rest of endoperidium.
Peristome dark brown, definite, with a prominent ring, $3.5-5.5 \mathrm{~mm}$ in diameter, sulcate. Peristome tube $1.5-3.0 \mathrm{~mm}$ high.

Capillitium threads long, slender, 1.6-6.4 $\mu \mathrm{m}$ thick, almost hyaline to pale brown, slightly cyanophilous in lactic blue, no significant response could be observed in Melzer's reagent. The surface of capillitium threads smooth or coarse due to small particles.

Spores brown, spherical, verrucose, $4.8-5.6 \mu \mathrm{m}$ in diameter, on average $5.2 \mu \mathrm{m}$ in diameter (incl. the verrucae, $\mathrm{n}=20$, material revived in Melzer's reagent). No significant response could be observed either in lactic blue or in Melzer's reagent.

\section{Ecology}

The locality in Björkör is a dry, stony meadow, alt. 3-4 $\mathrm{m}$, located between the main farm building (untenanted since 1960) and the seashore. The meadow was grazed by sheep. According to Andersson (1950:51), Geastrum nanum is in Sweden 'confined to districts where the rocky or loose strata contain lime'. On the Åland Islands the loose deposits are rich in Ordovician limestone (e.g. Brenner 1930, Eklund 1935), but this limestone is not very abundant in the Björkör area. Thus the vascular plant flora is rather poor and common (nomenclature according to Hämet-Ahti et al. 1977). The meadow contains low, scattered bushes of Juniperus communis, Rubus idaeus and Rosa caesia. In the field 


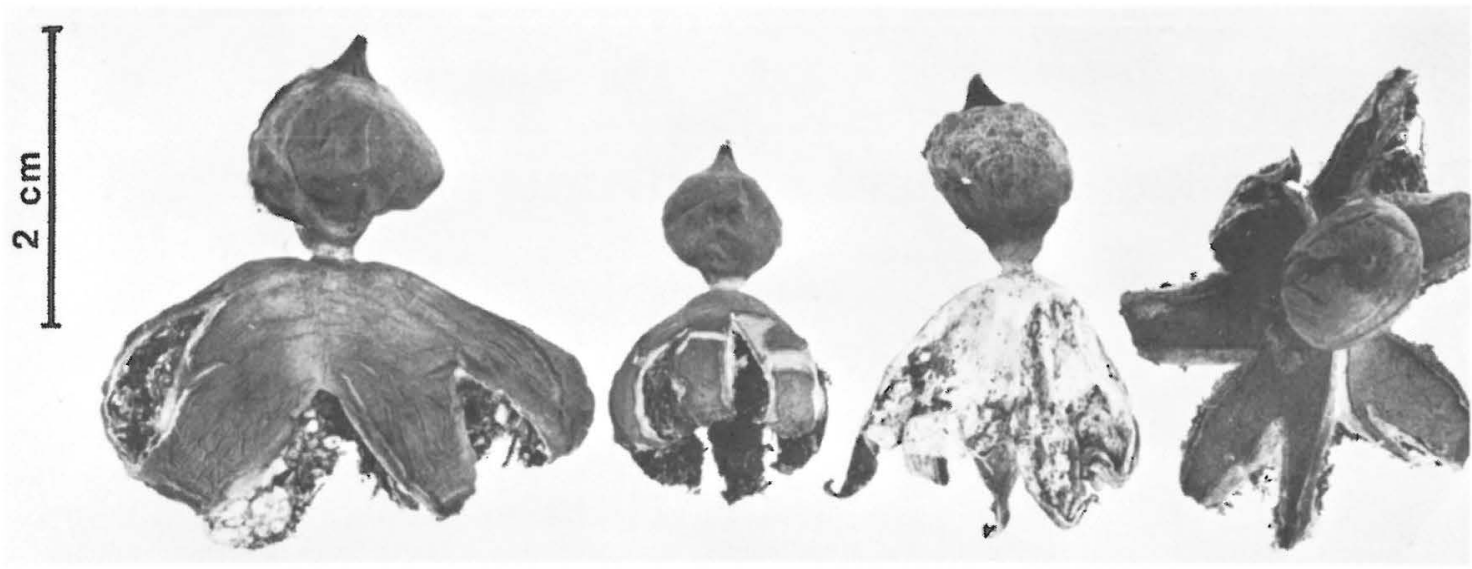

Fig. 1. Geastrum nanum Pers. from Björkör. Note the cracked lobes in the second gastrocarp from the left. The weathered gastrocarp is the third from the left. Photo Mauri Korhonen.

layer 37 species were recorded within $10-15 \mathrm{~m}$ from $G$. nanum. Many of these are typical of xerothermic sites in the SW archipelago of Finland, e.g. Sedum telephium, S. acre, Potentilla argentea, Hypericum perforatum, Arabis glabra, Silene viscosa, Dianthus deltoides, Galium verum, Achillea millefolium, Tanacetum vulgare, Hieracium pilosella, Festuca ovina, Deschampsia flexuosa, Agrostis tenuis and Elymus repens. Some calciphilous species (cf. Eklund 1946) were also recorded, e.g. Filipendula vulgaris, Alchemilla glaucescens, Geranium sanguineum, Arabis hirsuta, Arenaria serpyllifolia, Plantago lanceolata, Artemisia campestris and Allium oleraceum.

The ground layer consists of loose carpets and tufts of mosses and lichens, e.g. Dicranum scoparium Hedw., Hypnum cupressiforme Hedw., Rhytidiadelphus squarrosus (Hedw.) Warnst., Cetraria islandica (L.) Ach., Peltigera canina (L.) Willd. and Cladonia spp.

The humus layer is only $1-2 \mathrm{~cm}$ thick and merges gradually into the mineral soil, which consists mainly of sand and silt. The soil is slightly acid: $\mathrm{pH} 5.3$ and 5.4 (soil/aqua dest. 1/2.5, $\mathrm{pH}$ determined with a Radiometer PHM 24e).

\section{Total distribution}

Geastrum nanum has an extensive distribution. The nearest localities to Björkör are in Uppsala and Stockholm, Sweden (Andersson 1950). The species has been found in other places in Sweden, too: Gotland, Öland, Scania and Bohuslän (Andersson 1950). In Norway $G$. nanum has been recorded only twice (Eckblad 1955). In Denmark it is fairly common (Dissing \& Lange 1961).

Outside the Nordic countries $G$. nanum has been reported from several parts of Europe and also from Asia, North and Central America, East and South Africa and Australia (Andersson 1950, Stanck 1958. Dörfelt et al. 1979).

Acknowledgements. I wish to thank Dr. Harri Harmaja, who read the manuscript and made valuable suggestions, Mr. Stellan Sunhede, Göteborg, Sweden, who confirmed the determination of $G$. nanum, and Mrs. Anna A. Damström, M.A., who corrected the English text.

\section{References}

Andersson, O. 1950: Larger fungi on sandy grass heaths and sand dunes in Scandinavia. - Bot. Not. Suppl. 2(2): $1-89,9$ plates.

Brenner, W. 1930: Beiträge zur edaphischen Ökologie der Vegatation Finnlands 1. Kalkbegünstigte Moore, Wiesen und Wiesenwälder. - Acta Bot. Fennica $7: 1-97$.

Dissing, H. \& Lange, M. 1961: The genus Geastrum in Denmark. - Bot. Tidsskr. 57:1-27.

Dörfelt, H., Kreisel, H. \& Benkert, D. 1979: Karten der Pflanzenverbreitung in der DDR. 2. Serie. Die Erdsterne (Geastrales) der Deutschen Demokratischen Republik. - Hercynia N.F. 16:1-56.

Eckblad, F.-E. 1955: The Gasteromycetes of Norway. The epigaean genera. - Nytt Mag. Bot. 4:19-86.

Eklund, O. 1935: Silurmoränen i Skärgårdshavet. (Referat: Die silurischen Moränen des Schärenarchipels SWFinnlands.) - Terra 47:147-151.

_'- 1946: Úber die Kalkabhängigkeit der Kormophyten SW- 
Finnlands. - Memoranda Soc. Fauna Flora Fennica 22:166-187.

Hämet-Ahti, L., Jalas, J. \& Ulvinen, T. 1977: Suomen alkuperäiset ja vakiintuneet putkilokasvit. - Helsingin Yliopiston Kasvitieteen Laitoksen Monisteita 44:1-77.

Roivainen, H. 1960: Helsingin Yliopiston Kasvimuseon itäfennoskandisten itiökasvikokoelmien kasvu 1958-59.
Tillväxten av de östfennoskandiska kryptogamsamlingarna vid Helsingfors Universitets Botaniska Museum 1958-59. - Memoranda Soc. Fauna Flora Fennica 35:149-150.

Stan̋̌k, V.J. 1958: Geastraceae. - In: Pilát, A. (ed.), Flora ČSR, B1, Gasteromycetes: 392-526. Praha.

Accepted for publication

on May 21, 1979 